\title{
Exploring the Impact of Airlines Service Quality on Customer Loyalty: Evidence from Taiwan
}

\author{
Chun-Mei Chen ${ }^{1} \&$ Hsian-Ming Liu ${ }^{2}$ \\ ${ }^{1}$ Department of Business Administration, China University of Technology, Taiwan (R.O.C.) \\ ${ }^{2}$ Department of Financial Management, National Defense University, Taiwan (R.O.C.) \\ Correspondence: Chun-Mei Chen, Department of Business Administration, China University of Technology, \\ Taiwan (R.O.C.). E-mail: doris888@cute.edu.tw
}

Received: December 21, 2016

Accepted: April 14, 2017

Online Published: April 27, 2017

doi:10.5539/ijbm.v12n5p36

URL: https://doi.org/10.5539/ijbm.v12n5p36

\begin{abstract}
The purpose of this paper tries to explore what are the key factors to influence customers to choose an airline. The research assesses the service quality, brand image, perceived value and customer loyalty on Taiwan-based airlines. The study analyzes the data by applying structure equation modeling (SEM) from valid 560 questionnaires surveyed in the airports. To validate the measurement model, this study checks scale reliability, overall model fit, and validity using the CFA technology. Moreover, the two major indicators including convergence validity and discriminate validity were employed to assess scale validity. Many prior studies had proved that brand image has a positive influence on perceived value, this study had validated that perceived value has also a positive influence on brand image. The brand image assists in the relation between service quality and loyalty, and perceived value strengthens their relationship. Furthermore, brand image and perceived value mediate the effect of service quality on customer loyalty to display a distal effect. The strategic implications for the effects of service quality lead to repurchase intention and loyalty inclination, which are contributed to both scholarly advancement of knowledge and the state of managerial practice.
\end{abstract}

Keywords: service quality, brand image, perceived value, customer loyalty, airlines

\section{Introduction}

The diverse food culture, relatively cheap prices, human touch, and eastern rural scenery have long attracted tourists to visit Taiwan. The tourism market and travel-related industries in Taiwan have significantly developed over the past few decades. The rapid growth of inbound tourists has exceeded the growth of outbound tourists in Taiwan. The proportion of Taiwan's inbound tourists compared to total inbound tourists registered as $36 \%$ in 2001, but rapidly grew to $71.89 \%$ in 2015 (Tourism Bureau in Taiwan). Compared to 2005, the growth of Taiwan's inbound tourists in 2015 was $209 \%$, which was higher than the $60.7 \%$ growth for outbound tourists (please see Figure 1).

Since August 31, 2009 when direct cross-strait air transportation opened between Taiwan and China, regular weekly flights have increased to 890 by November 2015, connecting 61 cities on the Mainland China with 10 cities in Taiwan (Mainland Affairs Councils, Taiwan). Hence, Taiwan has become a target of interest by international airlines and low-fare airlines as a hub to set up their transit points for other flight routes regardless of recent cooling down due to political factors.

The market competition between airlines has become more intense and the delivery of high-quality service is essential for the airlines' survival. Thus, the issue of service quality is receiving greater attention and has become a critical antecedent of behavioral intentions than ever before (Hussain et al., 2015). The effects of the airlines-within-airlines strategy adopted by Qantas airline group showing pricing benefits are derived from service quality improvements as well as increased market power (Homsombat et al., 2014). Moreover, the perceived quality also has some crossover effects on other customer-level factors, such as customer value as well as brand image (Tasci, 2016).

Park et al. (2004) analyzed perceived price, service quality, perceived value, passenger satisfaction, and airline image to determine the passengers' future behavioral intentions. Chen and Chen (2010) investigated the visitor experience of heritage tourism and presented the relations in the following order, 'experience quality $\rightarrow$ perceived 
value $\rightarrow$ satisfaction $\rightarrow$ behavioral intentions'. Lai and Chen (2011) conceptualized relationships among passenger behavioral intentions, service quality, perceived value, and satisfaction. Wang and Tsai (2014) examined for the effects of brand image, perceived quality, perceived risk, perceived value, and loyalty, and brand image did indeed increase the customers' loyalty.

Previous studies have revealed that service quality, brand image, perceived quality, loyalty, customer satisfaction are the main factors to improve airlines' performance. Nevertheless, there are a few studies to explore the crossover effect of service quality and its influence process on tourist behavioral intentions. Therefore, this study employed perceived value and brand image as mediators to explore the crossover effects of service quality for the customers on their loyalty.

Moreover, Taiwan's aviation industry is facing a high degree of competition and the engaging market impact of low-cost carriers (LCC). This background and development inspires us to explore the relationship among service quality, brand image, perceived value and customer loyalty, and to provide a reference for marketing and strategy management by academia, practitioners, and transport operators.

\section{Tourists Growth and Airlines Analysis}

\subsection{Tourists Growth}

The government policy of 'multiple layout, think globally' to attract tourists to Taiwan has been outstandingly successful. Taiwan's inbound and outbound passengers in 2015 totaled 23,623 thousand, surpassing the country's population of 23,496 thousand (please see Figure 1). Compared to 2005, in 2015 there were 10,439 thousand inbound tourists for a growth ratio of $209 \%$, which was higher than the $60.7 \%$ for 13,183 thousand outbound tourists (Tourism Bureau in Taiwan). In 2015, outbound tourists from Taiwan to Japan hit 28.8\% (the highest number), with the next highest amount to Mainland China at $25.8 \%$, followed by $15.2 \%$ to Hong Kong, $4.5 \%$ to Thailand, $4.0 \%$ to Macao, $3.6 \%$ to the United States, 3.1\% to Vietnam, and $1.2 \%$ to European countries. Additionally, $93.7 \%$ of outbound tourists from Taiwan traveled to other Asia countries.

In 2015, the proportion of Taiwan's inbound tourists compared to total inbound passengers reached $71.89 \%$ (Tourism Bureau in Taiwan). Taiwan's inbound tourists only registered 3,378 thousand in 2005, but by 2011 they had displayed huge growth, hitting 10,439 thousand. The majorities of inbound tourists came from Mainland China, to occupy $40.1 \%$ of Taiwan's total tourists. Tourists from Japan totaled $15.6 \%$, and the combined tourists from H.K. and Macao were $14.5 \%$. The tourists from S. Korea comprised $6.3 \%$ and the tourists from the United States tallied 4.6\%. Finally, the tourists from Malaysia registered 4.1\% (Tourism Bureau in Taiwan). Figure 1 illustrates the growth trends of Taiwan's outbound and inbound tourists.

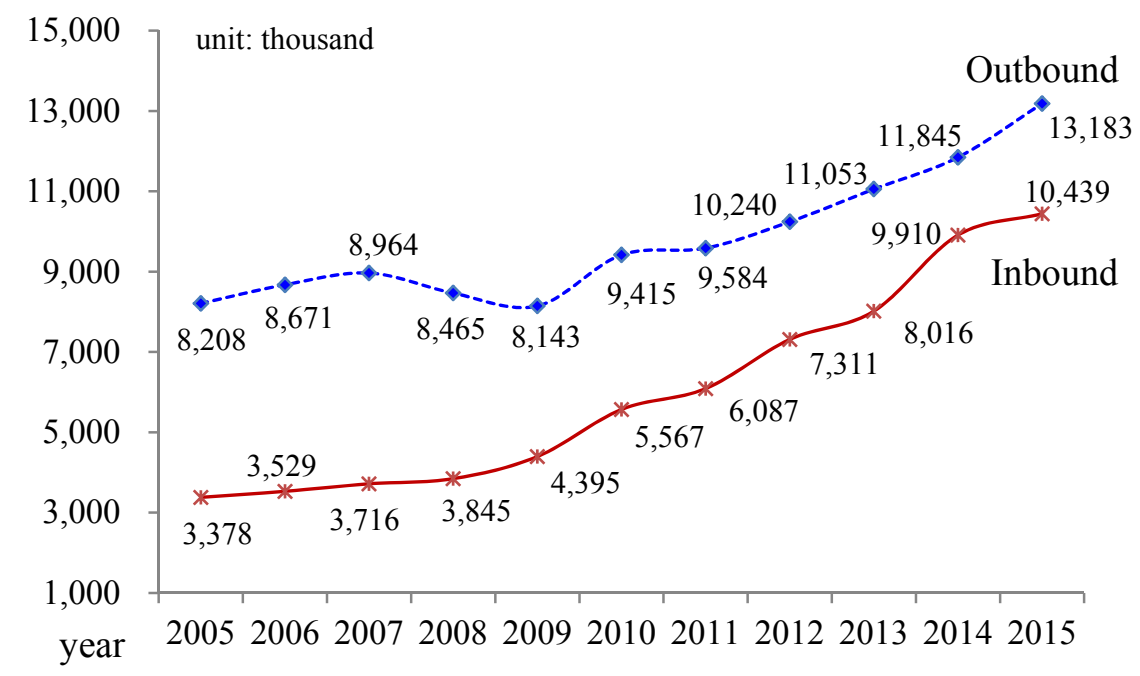

Figure 1. Growth trends of Taiwan's outbound and inbound tourists

Source: Taiwan Tourism Bureau, MOTC.

\subsection{Airlines Analysis}

Chou et al. (2014) validated that Asia was the most affected by Taiwan's opening-up to Chinese tourists' policy while Europe and Oceania were less affected in terms of regional effects. By the end of 2015, Taiwan had a total 
of nine national airlines, with only Daily Air (formerly known as Marsh Aviation) operating local routes to remote outlying islands. Uni Air and Mandarin Airlines are responsible for local and Asia regional routes and are under the umbrella of EVA Air and China Airlines, respectively.

For the outbound passenger market share, all the foreign airlines have increased year by year, growing from 40.93\% in 2012 to $43.3 \%$ in 2015 (Tourism Bureau in Taiwan). In 2015, the outbound passenger market shares of Taiwan's airlines hit the rest of $56.7 \%$, including China Airlines at $25.42 \%$, EVA Air at $21.14 \%$, TransAsia at $3.77 \%$, Mandarin Airlines at $2.58 \%$, Tigerair Taiwan at $1.71 \%$. The outbound passenger market share grew for operators such as Scoot at $1.6 \%$ in 2014 to $1.71 \%$ in 2015 . As for Tigerair Taiwan, which was at $0.7 \%$ in 2014 increased to $1.71 \%$ in 2015 (Tourism Bureau in Taiwan).

\section{Literature Review and Hypotheses}

\subsection{Service Quality}

A comparison of consumer expectations with performance to build up service quality perception and evaluation depends on the process and outcome of service delivery (Parasuraman et al., 1985). Service quality was defined as the assessments of the customers about a product's overall excellence or superiority (Zeithaml, 1988). The 'service quality' is tacit to encompass the knowledge, skills, and experience of managers which the managers utilized within a firm (Hitt, et al. 2001; Kor, 2003).

The service quality is received by the end customers for the measurement of satisfaction level for the firms' offerings. Kristensen et al. (1999) indicated that customers should be able to achieve true satisfaction with the inferred quality and value of goods/services. Service quality has a significant impact on business performance, business costs, customer satisfaction, customer loyalty and profitability (Seth et al., 2005). Lee (2006) showed that customer satisfaction is the leading criterion for determining quality, including satisfaction with the quality of a product, an ongoing business relationship, and the price or performance ratio to meet customer expectations.

Clemes et al. (2008) indicated that for achieving a high level of satisfaction, a high standard of service quality should be delivered by the service provider. Thus, satisfaction means that the enterprise must deliver as much or more value than the consumers initially expected, and offer enough to satisfy their needs. Lai and Chen (2011) conceptualized relationships among service quality, perceived value, satisfaction, and passenger behavioral intentions.

Regarding the conceptualization of service quality, Parasuraman et al. (1988) proposed a SERVQUAL model with five constructs of tangibles, reliability, responsiveness, assurance, and empathy. However, many authors (Cronin \& Taylor, 1992; Culiberg, 2010; Hussain et al., 2015) have questioned its wide application for measuring all aspects of an industry without modifications (Culiberg, 2010). Chen and Chen (2010) investigated the visitor experience of heritage tourism and presented that customer experience quality has a significant distal effect on behavioral intentions.

Tsaur et al. (2002) evaluated the service quality of airlines to propose that the most concerned attributes are courtesy, safety, and comfort. Hussain et al. (2015) altered the measurement of service quality by including security and safety, and communications for evaluating the service quality in the aviation industry. In conclusion, to measure the level of service quality being applicable to the aviation industry, this study based on the SERVQUAL model to include the concept of 'security and safety' in 'reliability', and 'communication' in 'empathy'. Please see question items 1-15 in Appendix 1.

\subsection{Brand Image}

An organization with a positive corporate image is more likely to retain current customers and attract new customers (Connor \& Davidson, 1997). There are three types of benefits viewed as consequences from the purchase or consumption of a brand: functional benefits, symbolic benefits, and experiential benefits (Keller, 1993; Park et al., 1986). 'Functional benefits' are related to the intrinsic advantages from the consumption of product or services. 'Symbolic benefits' are associated with the underlying needs for the social approval or personal expression of customers. 'Experiential benefits' refer to what the customers felt when they used the product or services.

Other experiential benefits that consumers seek through brands may include sensory pleasure, variety, and cognitive stimulation (Keller, 1993). Fredericks and Slater (1998) also highlighted that the decision of customer perceived value comes from the brand image, and simultaneously will affect customer loyalty. A corporate brand image is a valuable intangible form of capital that is hard to imitate and can help an organization to achieve a sustainable and superior financial performance (Roberts \& Dowling, 2002). 
A corporate image serves as an important determinant of customer satisfaction and influences brand loyalty (Wu, 2011). Corporate image can be defined as the perception of an organization reflected in the associations held in the consumers' memory, which distinguish the organization from other competitors (Elgin \& Nedunchezhian, 2012; Hussain et al., 2015). The more reputable an airline is, the more trust it can build (Hussain et al., 2015). Wang and Tsai (2014) proposed that there are positive and direct effects among brand image, perceived quality, perceived value, and loyalty, and that brand image indeed increases the loyalty.

In the airline industry, a corporate brand image plays a vital role in attracting tourists, and to form the differential with other competitors. Brand image can leverage positive consumer behavior by means of providing social public benefits, sponsorship activities, and a preferential pricing program to attract more buyers. Since flight accidents can significantly affect tourist loyalty, how to provide a secure and safe service is critical. Thus, the related concept of 'brand image' under this study is composed of functional benefits, symbolic benefits, and experiential benefits (Park et al., 1986). Please see question items 16-21 in Appendix 1.

\subsection{Perceived Value}

For the related construct of perceived value, most studies in the literature focus on measuring the product recognized value from a consumer dimension. Dodds and Monroe (1985) identified the relationship models of price, perceived quality, and perceived value and mentioned that perceived value is an important factor in the consumer purchasing decision process. Parasuraman and Grewal (2000) indicated that perceived value is an important index for those customers in a status to repurchase. The perceived value is explored to imply an interaction between a consumer and a product (Raquel \& Ángeles, 2007).

Sweeny and Soutar (2001) induced the construct of perceived value, which includes the four dimensions of perceived quality, emotional value, social value, and price to figure out the PERVAL scale. Petrick (2002) proposed that perceived value of service comprises five dimensions: quality, emotional response, monetary price, behavioral price and reputation. Perceived quality is simply the customer's overall assessment of the standard process of receiving customer services (Hellier et al., 2003). During the process of consuming a product or service, how to satisfy the consumer's perceived value and further to garner a good impression on the corporation is a very important issue for enterprises (Kuo et al., 2009).

Wang et al. (2015) estimated the perceived value for the transit time of containers by a shipping line's published schedule, which is the optimal decision to minimize the sum of fuel costs and time-associated costs. From the literature explored above, this study is based on the research of Sweeny and Soutar (2001) to measure perceived value, which includes the attributes of perceived quality, emotional value, social value, and price. Please see question items 22-27 in Appendix 1.

\subsection{Customer Loyalty}

Jones and Sasser (1995) proposed three characteristics of customer loyalty: (1) Intention to repurchase; (2) Primary behavior-frequency of purchase, consistency of purchasing and length of being a customer; (3) Secondary behavior-providing information and recommending to others. Moreover, Prius and Brandt (1995) pointed out that customer loyalty includes intention of repurchasing, purchasing other products and services of the same company, and the intention of recommending to others. Since replacing lost customers comes at an elevated cost, customer defection should be a key performance gauge for senior management and a fundamental component of incentive programs (Zeithaml et al., 1996).

Several studies in the marketing literature have primarily investigated the relation between perceived quality and loyalty (Alexandris et al., 2002; Cronin, 2000; Wang et al., 2004). Re-purchase intention is the repeated process of buying goods or services from a particular store or place, and the main reason is in the experiences after shopping (Hellier et al., 2003). Kuo et al. (2013) indicated that both consumer inertia and satisfaction positively influence repeat - purchase, and that consumer inertia is more influential than satisfaction. Wang and Tsai (2014) validated that there are positive and direct effects among brand image, perceived quality, perceived value, and loyalty.

In other words, when customers perceive better products or service value, they then form purchase intention to result in habitual buying behavior. Even though customers have a purchase intention to choose an airline, they may finally give up, because the price might be too expensive or due to a lack of promotional programs. Based on Jones and Sasser (1995)'s study, the related constructs of customer loyalty under this study are composed of recent purchase activities, re-purchase intention, and recommendation intention. Please see question items 28-33 in Appendix 1.

\subsection{Hypotheses}


The association among the above-mentioned constructs of service quality, brand image, perceived value, and customer loyalty is closely related to prior research. Anderson and Sullivan (1993) stated that quality can be perceived without previous consumption experience and does not normally depend on price, and perceived value will positively influence brand loyalty. Satisfaction or dissatisfaction is an immediate response to consumption, while 'service quality' is interpreted as the overall impression of a customer's judgment concerning the service provided (Bitner \& Hubbert, 1994; Culiberg, 2010; Hussain et al., 2015).

Thus, the customer satisfaction is connected to the level of service quality, which the passengers perceived value from the overall service quality provided by the airlines. The determination of perceived value come from brand image, and further to affect customer loyalty had been validated (Fredericks \& Slater, 1998). Perceived value plays an important role in building customer confidence, more the perceived value and then more the customer loyalty (Sirdeshmukh et al., 2002). The positive brand image and perception can enhance customer purchase intention and lead to customer loyalty (Romaniuk \& Sharp, 2003).

Therefore, this research framework is included for four related constructs of service quality, brand image, perceived value, and customer loyalty to explore passenger purchase behavior. The SERVQUAL framework has been utilized to measure the level of service quality, including the attributes of tangibility, reliability, responsiveness, assurance, and empathy (Parasuraman et al., 1988). The flight service quality for the concept of 'security and safety' is surveyed in the item of assurance, and the concept of 'communication' is surveyed in the item of empathy to better fit with the SERVQUAL framework.

Furthermore, brand image is included for the attributes of functional benefits, symbolic benefits, and experiential benefits which was proposed by Park et al. (1986). The perceived value is included in the attributes of perceived quality, emotional value, social value, and price (Sweeny \& Soutar, 2001). The customer loyalty is included in the attributes of recent purchase activities, repurchase intention, and purchase recommendation (Jones \& Sasser, 1995). Because a positive purchase intention will cause recent purchase activities, it can further form re-purchase intention and recommendation intention to be loyalty inclination.

Concluding the above prior studies, this paper proposed to figure out a research framework as shown in Figure 2. The aim of this paper is to explore and assess what are the key factors influencing customers in choosing an airline. The demographic variables of sex, age, educational degree, occupation and income/per month for this study are set as the control variables. Hence, Hypothesis 1 (H1), Hypothesis 2 (H2), and Hypothesis 3 (H3) are the subjects to be verified. Whether the brand image mediates the relationship between service quality and the customer loyalty or the perceived value mediates the relationship between service quality and customer loyalty are subjects to be verified in Hypothesis 4 (H4) and Hypothesis 5 (H5). Moreover, the distal effect between brand image and perceived value, which mediates the effect of service quality on customer loyalty, is another subject to be verified in Hypothesis 6 (H6). For the research model, please refer to Figure 2.

$\mathrm{H} 1$ : Service quality is positively related to customer loyalty.

$\mathrm{H} 2$ : Brand image is positively related to customer loyalty.

H3: Perceived value is positively related to customer loyalty.

H4: Brand image mediates the relation between service quality and customer loyalty.

H5: Perceived value mediates the relation between service quality and customer loyalty.

H6: The distal effect between perceived value and brand image mediates the effect of service quality on customer loyalty. 


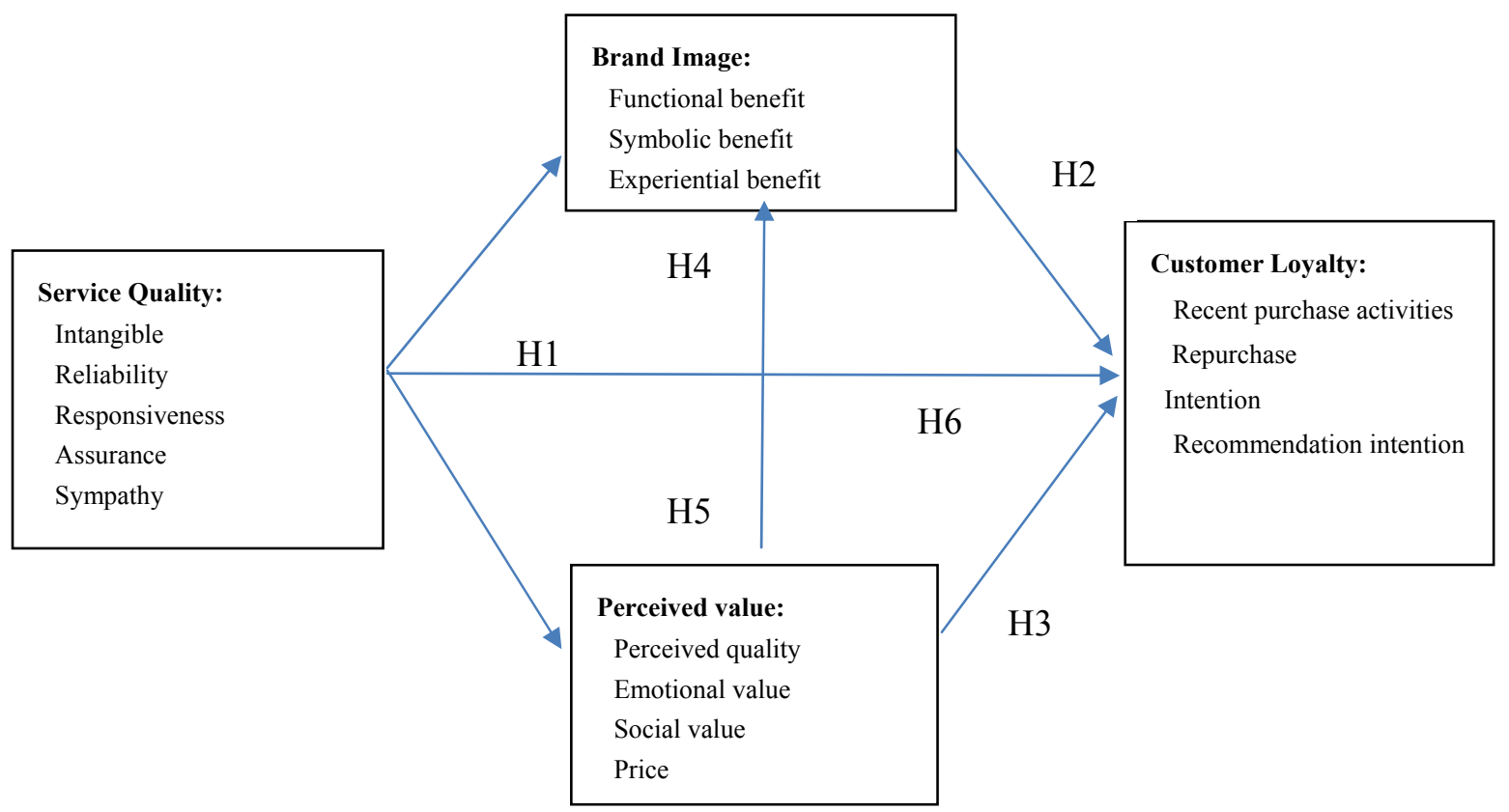

Figure 2. Research framework

\section{Methodologies and Data Analysis}

\subsection{Data Collection and Sampling}

The sampling design used for the survey was a non-probability convenience sample, based on time constraints and accessibility to respondents. This structured questionnaire was designed to measure the satisfaction degree of service quality, perceived value, brand image, and customer loyalty for China Airlines, EVA Air and TransAsia. To ensure authenticity of the materials, data was collected via face-to-face interviews to acquire the traveler's actual feedback and to mitigate any weaknesses in the market survey.

A total of 600 questionnaires were distributed, with 450 questionnaires collected from Taoyuan International Airport and 150 questionnaires received from Taipei Song-Shan Airport during the period February-March 2016. This survey adopted a self-reported questionnaire, gathering information and achieving a $93.3 \%$ recovery ratio for a total 560 valid questionnaires: 240 questionnaires were filled out each for China Airlines and EVA Air, and 80 for TransAsia based on the market share ratios.

The respondents responded on a five-point Likert-type scale for a total of fifteen questions covering service quality, ranging from 5 'very satisfied' to 1 'very unsatisfied', to measure the levels of brand image, perceived value, and customer loyalty. For the involvement degree of the respondents to choose an airline, the most important factors in order from highest to lowest are 'to provide a secure and safe travel service' $(59.1 \%)$, 'the service attitude of airlines is good' $(14.1 \%)$, 'the brand image is good' $(12.9 \%)$, and 'offer competitive prices versus other airlines' $(2 \%)$. For a more detailed profile of the respondents, the sample characteristics for the demographic variables of gender, age, educational degree, occupation, and income/month as shown in Table 1.

Table 1. Profile of respondents

\begin{tabular}{llll}
\hline Variable & Category & $\mathrm{n}$ & $\%$ \\
\hline Gender & Male & 260 & 46.0 \\
& Female & 300 & 54.0 \\
Age & under18 (include) & 27 & 4.8 \\
& $19-30$ & 273 & 48.8 \\
& $31-40$ & 154 & 27.5 \\
& $41-50$ & 86 & 15.4 \\
& $51-60$ & 17 & 3.0 \\
Educational degree & $60+$ & 3 & 0.5 \\
& Under junior high school & 12 & 2.1 \\
\hline
\end{tabular}




\begin{tabular}{llll}
\hline & University (College) & 399 & 71.3 \\
Occupation & Master degree & 71 & 12.7 \\
& Military \& government & 35 & 6.8 \\
& Service industry & 233 & 45.2 \\
& Technology industry & 69 & 16.8 \\
& Students & 133 & 11.4 \\
& Housekeeping & 18 & 4.2 \\
Monthly salary (NT\$) & Unemployed & 9 & 4.6 \\
& Others & 63 & 11.0 \\
& Less than 20,000 & 137 & 24.5 \\
& $20,001 \sim 30,000$ & 179 & 32.0 \\
& $30,001 \sim 50,000$ & 152 & 27.1 \\
& $50,001 \sim 70,000$ & 58 & 10.4 \\
\hline
\end{tabular}

\subsection{Data Analysis}

To run an appropriate examination of the research hypotheses, this study follows a two-step approach from Anderson and Gerbing (1988), conducting confirmatory factor analysis (CFA) to assess properties of the measurement model, and then subsequently testing the hypotheses. In addition, this study performed a self-reported survey and set up a path model, which were utilized to analyze the relations among the satisfaction of service quality, brand image, perceived value, and customer loyalty. This type of measurement and methodology usually exhibits the problem of common method variance (CMV).

To detect the impact of CMV, Harman's one factor test was employed to identify the presence of CMV. In this current study, there were four rotated factors with $66.6 \%$ variance, indicating that CMV is not a serious issue. Moreover, for enjoying some advantages to include fewer parameters to be estimated, more stable parameter estimates, and more definitive rotational results, this study adopts the technique of item parcels to transform all latent constructs into manifest variables to explore the proposed research framework (Hau \& Marsh, 2004).

\subsection{Measurement Model}

To validate the measurement model, this study checks scale reliability, overall model fit, and validity using the CFA technology. Initially, the three reliability measures including Cronbach's $\alpha$, composite reliability, and the average variance extracted (AVE) estimator were employed to assess scale reliability. The results of CFA indicated that Cronbach's $\alpha$ and the composite reliability ranged from 0.738 to 0.862 . Moreover, for each latent construct, the average variance extracted is close to or over 0.5 , representing that the minimum acceptable values reach all the constructs and that the scale of this study has appropriate reliability. Table 2 shows the summary of measurement model and the reliability analysis results.

Next, the two major indicators including convergence validity and discriminate validity were employed to assess scale validity. Convergence validity refers to the extent in which multiple items from a signal construct have high correlation and magnitude, which is usually evaluated by the significance of the standardized loadings of observed items onto their respective latent constructs. This significance implies that observed items load together on their respective latent constructs and provide much more explanatory power than the error variance. As shown in Table 2, the standardized loadings of all items for each construct are significant at the level of 0.05 , representing that the scale of this study has an appropriate level of convergence validity. 
Table 2. Summary of measurement model $(n=560)$

\begin{tabular}{|c|c|c|c|c|c|c|c|}
\hline Latent constructs & Items & Mean & SD & $\begin{array}{l}\text { Standardized } \\
\text { loading }\end{array}$ & Cronbach' $\alpha$ & $\begin{array}{l}\text { Composite } \\
\text { reliability }\end{array}$ & $\begin{array}{l}\text { AVE } \\
\text { estimate }\end{array}$ \\
\hline \multirow[t]{6}{*}{ Service quality } & & & & & 0.862 & 0.864 & 0.561 \\
\hline & Tangibles & 3.546 & 0.569 & $0.709^{* * *}$ & & & \\
\hline & Reliability & 3.748 & 0.643 & $0.665^{* * *}$ & & & \\
\hline & Responsiveness & 3.599 & 0.641 & $0.787^{* * *}$ & & & \\
\hline & Assurance & 3.632 & 0.647 & $0.792^{* * *}$ & & & \\
\hline & Empathy & 3.642 & 0.659 & $0.781^{* * *}$ & & & \\
\hline \multirow[t]{4}{*}{ Brand image } & & & & & 0.739 & 0.748 & 0.493 \\
\hline & Functional & 3.848 & 1.046 & $0.660^{* * *}$ & & & \\
\hline & Symbolic & 3.772 & 1.034 & $0.667^{* * *}$ & & & \\
\hline & Experiential & 3.664 & 1.105 & $0.774^{* * *}$ & & & \\
\hline \multirow[t]{5}{*}{ Perceived value } & & & & & 0.793 & 0.800 & 0.501 \\
\hline & Perceived quality & 3.629 & 0.622 & $0.723^{* * *}$ & & & \\
\hline & Emotional value & 3.663 & 0.640 & $0.775^{* * *}$ & & & \\
\hline & Social value & 3.713 & 0.783 & $0.664^{* * *}$ & & & \\
\hline & Price & 3.677 & 0.785 & $0.664^{* * *}$ & & & \\
\hline \multirow[t]{4}{*}{ Customer loyalty } & & & & & 0.738 & 0.743 & 0.493 \\
\hline & Recent purchase activities & 3.602 & 0.705 & $0.604^{* * *}$ & & & \\
\hline & Re-purchase intention & 3.613 & 0.732 & $0.755^{* * *}$ & & & \\
\hline & Recommendation intention & 3.559 & 0.796 & $0.737^{* * *}$ & & & \\
\hline
\end{tabular}

Discriminant validity refers to the extent in which items from different constructs are distinct from each other. This study utilizes the $\chi^{2}$ difference test to verify discriminant validity. The methodology of the $\chi^{2}$ difference test is used to calculate the difference between the full model, where all correlations are free to be estimated, and the restricted model, in which the correlation of assessed constructs is constrained to be unity and others can be allowed to be free.

If all estimates of the $\chi^{2}$ difference test for each pair of constructs are significant, then discriminant validity is concluded to exist (Bagozzi et al., 1991). Table 3 summarizes the results of examining discriminant validity. The result confirms that all estimates of the $\chi^{2}$ difference test for any pair of constructs are significant at the level of 0.05 ( $\chi^{2}$ difference $\left.>3.84\right)$, exhibiting that the scale of this study has a sufficient level of discriminant validity.

Table 3. Results of discriminant validity $\left(\chi^{2}\right.$ difference test)

\begin{tabular}{llll}
\hline Latent constructs & Service quality & Brand image & Perceived value \\
\hline Brand image & $131.871^{* * *}$ & & \\
Perceived value & $234.436^{* * *}$ & $16.262^{* * *}$ & \\
Customer loyalty & $151.281^{* * *}$ & $40.685^{* * *}$ & $46.235^{* * *}$ \\
\hline
\end{tabular}

Note: ${ }^{* *} \mathrm{p}<0.05 ;{ }^{* * *} \mathrm{p}<0.01$.

After the reliability and validity of the scale have met the criteria, the overall model is considered, with the relevant indices of goodness of fit indices of the structure model presented in Table 4. Among these fit measures, $\chi^{2} / \mathrm{df}$ is 3.813; the goodness of fit $(\mathrm{GFI}=0.926)$, comparative fit index $(\mathrm{CFI}=0.939)$, normed fit index $(\mathrm{NFI}=$ $0.920)$, and non-normed fit index $(\mathrm{NNFI}=0.94)$ are above the acceptable value of 0.9.

In addition, the root means square residual (RMR) of 0.02 and the value of RMSEA of 0.071 are significantly below the suggested values of 0.05 and 0.08 , respectively. These indices indicate that the measurement model is adequate, indicating that the measurement model of the theoretical framework provides an appropriate fit with the actual data. Therefore, the hypothesized measurement model is reliable and meaningful to test the mediation and moderation effects among the constructs. 
Table 4. Fit indices of structure model

\begin{tabular}{ll}
\hline$\chi^{2}$ & 320.274 \\
df & 84 \\
$\chi^{2} / d f$ & 3.813 \\
Goodness of fit (GFI) & 0.926 \\
Normed fit index (NFI) & 0.920 \\
Non-normed fit index (NNFI) & 0.924 \\
Comparative fit index (CFI) & 0.939 \\
RMR & 0.020 \\
RMSEA & 0.071 \\
\hline
\end{tabular}

\subsection{Path Model}

\subsubsection{Direct effects}

The analysis results of the research model are reported in Figure 3 and Table 5. First, it could be seen that the standardized direct effect of service quality to customer loyalty is significant $(0.192 ; p<0.001)$, supporting the notion that an airline company with better service quality for the tourists has a positive and significant impact on customer loyalty, providing strong support for H1. Second, the standardized path coefficient of brand image on customer loyalty is $0.282(\mathrm{p}<0.001)$, providing significant support for $\mathrm{H} 2$. This result indicates that airline companies with a superior brand image exhibit high levels of loyalty by customers.

The path coefficient from perceived value to customer loyalty is also significant $(0.334 ; p<0.001)$, supporting the notion that perceived value has a positive impact on customer loyalty, leading support to H3. This result indicates that firms with a greater perceived value from their customers will lead those customers to higher levels of customer loyalty. Thus, Table 5 illustrates the summary of direct effects that customer loyalty is positively influenced by service quality, brand image, and perceived value. The results of the research model are shown in Figure 3.

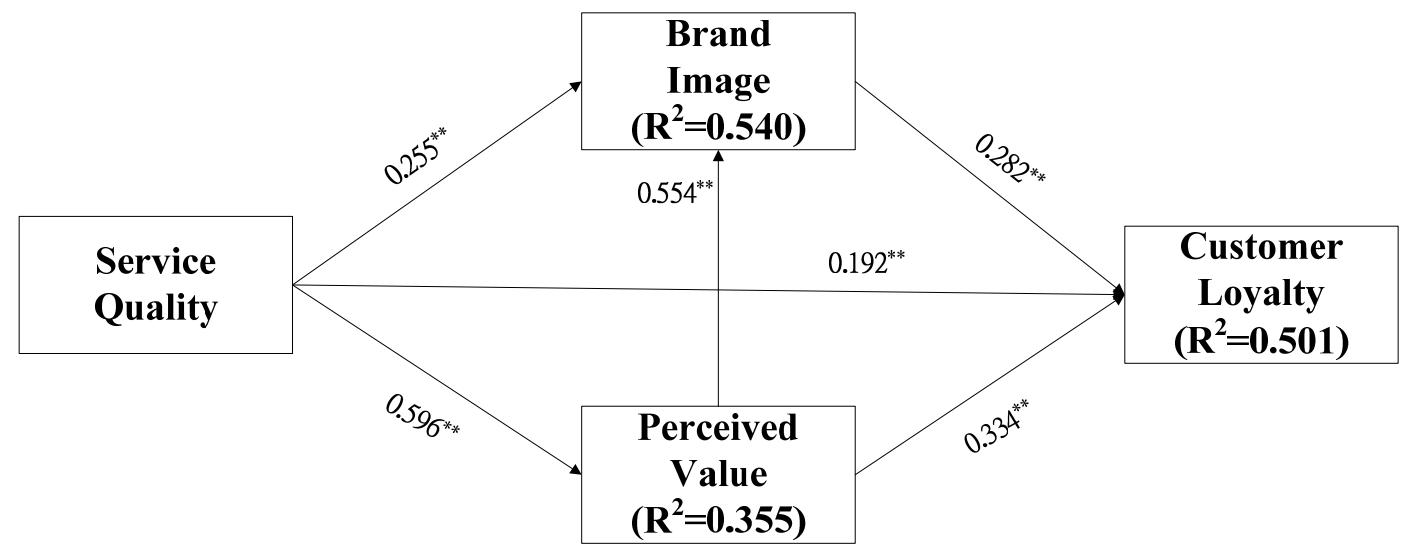

Figure 3. Results of the research model

${ }^{* *} \mathrm{p}<0.05 ;{ }^{* * *} \mathrm{p}<0.01$.

\subsubsection{Indirect Effects}

Table 5 illustrates the estimating and testing of mediating effects. First, it could be seen that the total effect of service quality on customer loyalty is 0.662 and can further be decomposed into a direct effect $(0.229)$ and an indirect effect (0.433). The 95\% confidence interval constructed by bootstrapping indicates that both the direct effect and the indirect effect do not involve zero, indicating that the significant impact of service quality on customer loyalty not only arises from the direct effect, but also from the indirect effect. Therefore, further to explore the indirect effect relation between service quality and customer loyalty and whether brand image and perceived value can mediate this relationship, three mediation effects will be further examined.

Brand image and perceived value are first employed separately as the mediator. Thus, the mediated effect of brand image is 0.086 . The $95 \%$ confidence interval of the percentile method is between 0.051 and 0.126 , and 
$19.8 \%$ of the total indirect effect can be explained, indicating that brand image as a mediator of the service quality- customer loyalty nexus provides significant support for H4. Second, the mediated effect of perceived value is 0.236 . The $95 \%$ confidence interval of the percentile method is between 0.026 and 0.318 , and $54.5 \%$ of the total indirect effect can be explained, indicating that perceived value as a mediator of the service quality-customer loyalty nexus is significantly supported and leads to support H5.

Table 5. Estimating and testing of mediating effects

\begin{tabular}{|c|c|c|c|c|c|c|}
\hline \multirow{4}{*}{ Construct } & \multirow{4}{*}{ Estimate } & \multicolumn{4}{|c|}{ Bootstrapping } & \multirow[b]{4}{*}{ Upper } \\
\hline & & \multirow{3}{*}{$\begin{array}{l}\text { Standard } \\
\text { Error }\end{array}$} & \multirow{2}{*}{\multicolumn{2}{|c|}{$\begin{array}{l}\text { Bias-Corrected } \\
95 \% \mathrm{CI}\end{array}$}} & \multirow{2}{*}{$\begin{array}{l}\text { Percentile } \\
95 \% \mathrm{CI}\end{array}$} & \\
\hline & & & & & & \\
\hline & & & Lower & Upper & Lower & \\
\hline \multicolumn{7}{|l|}{ Service quality $\rightarrow$ Customer loyalty } \\
\hline Total effect & $0.662^{* * *}$ & 0.049 & 0.564 & 0.755 & 0.563 & 0.755 \\
\hline Direct effect & $0.229^{* * *}$ & 0.041 & 0.151 & 0.310 & 0.152 & 0.312 \\
\hline Indirect effects & $0.433^{* * *}$ & 0.040 & 0.360 & 0.512 & 0.357 & 0.510 \\
\hline Service quality $\rightarrow$ Brand image $\rightarrow$ Customer loyalty & $0.086^{* * *}$ & 0.026 & 0.055 & 0.133 & 0.051 & 0.126 \\
\hline $\begin{array}{l}\text { Service quality } \rightarrow \text { Perceived value } \rightarrow \text { Customer } \\
\text { loyalty }\end{array}$ & $0.236^{* * *}$ & 0.019 & 0.160 & 0.159 & 0.026 & 0.318 \\
\hline $\begin{array}{l}\text { Service quality } \rightarrow \text { Perceived value } \rightarrow \text { Brand image } \rightarrow \\
\text { Customer loyalty }\end{array}$ & $0.111^{* * *}$ & 0.041 & 0.064 & 0.166 & 0.062 & 0.165 \\
\hline
\end{tabular}

Note: 1. 2,000 bootstrap samples.

$2 .{ }^{* *} \mathrm{p}<0.05 ;{ }^{* * *} \mathrm{p}<0.01$.

Fredericks and Slater (1998) indicated that brand image has a positive influence on customer perceived value. However, customer perceived value on an airline leading to a brand image should be accumulated long term, including the frequencies of flight safety, service satisfaction level, and other factors. Conversely, this study looks to prove that perceived value has a positive influence on brand image. This research employs the distal model to examine the effect of service quality on customer loyalty through two major factors: brand image and perceived value.

In this path analysis, the mediated effect is 0.111 and the $95 \%$ confidence interval of the percentile method is between 0.062 and 0.165 , representing that the impact of the distal effect is significant and $25.6 \%$ of the total indirect effect can be explained, leading support to H6. Therefore, the results of the main effect and mediating effect identify that service quality and loyalty are being mediated by brand image and perceived value. The results of the hypotheses testing are thus all supported as shown in Figure 3.

\section{Discussion}

\subsection{Direct Effect}

The empirical results show that service quality, brand image and perceived value have a direct effect on customer loyalty $(\mathrm{H} 1, \mathrm{H} 2, \mathrm{H} 3)$. The level of service quality for the passengers perceived is a significant and important driver of brand image and perceived value on the consuming motivation of purchase process. When the passengers receive good experience quality, they perceive it with positive value and are more willing to pay a higher price, which leads to higher customer loyalty.

\subsection{Mediated Effects}

Many studies have proved that a corporate brand image has a positive influence on customer perceived value. However, because customer perceived value on a corporate brand should be accumulated over the long term, this study has proved that customer perceived value also has a positive influence on brand image. This research employs the distal model to examine the effect of service quality on customer loyalty through two major items: brand image and perceived value. The mediated effect of brand image has been validated to play as a mediator of the service quality- customer loyalty nexus (H4). 
Moreover, the mediated effect of perceived value has been validated to act as a mediator of the service quality-customer loyalty nexus (H5). The results confirm that a tourist's perceived service quality can assist in enhancing the airlines brand image by improving the perceived value, and then to create a positive synergy effect on customer loyalty (H6). In November 22, 2016, TransAsia announced to cease all the flight service due to the unbearable financial losses. It has proved that the level of service quality affects customer purchase intention and loyalty inclination, and further to impact enterprises survival.

\section{Conclusion, Limitations, and Further Research}

This study employs a reliable hypothesized measurement model when testing how the level of service quality impact customer loyalty through both mediators of brand image and perceived value. Many prior studies had proved that a corporate brand image has a positive influence on perceived value. This is the first study of the reverse case, which contends that perceived value has also a positive influence on brand image. This paper contributes to the literature by proving that when a passenger is satisfied with the flight service quality, he will exhibit a higher level of purchase activities and ultimately lead to customer loyalty.

Other than the airline samples, many prior studies had applied the research structure of service quality to understand customer loyalty in many industry firms. Nevertheless, this study has deliberately explored the spill-over benefits of service quality on customer loyalty by ways of improving brand image and perceived value. The findings have displayed that brand image assists in the relation between service quality and customer loyalty, and perceived value strengthens the relationship between service quality and customer loyalty. Both mediators of perceived value and brand image assist in the effect of service quality on the purchase intention and customer loyalty.

By enhancing their respective perceived value and brand image, China Airlines and EVA Air had improved their financial performance in 2015. However, the Keelung River air crash seriously hurt TransAsia's flight safety quality and brand image, thus resulting in its passenger loss and finally suspend all the flight business. This study finds that the key consideration factor for the tourists in choosing an airline is to 'get secure and safe travel service,' which accounts for $59.1 \%$ of the respondents. Therefore, how to provide a secure and safe flight service is the highest concern in terms of management issues for the worldwide airlines.

Despite the good fit of service quality model leading to purchase activities and loyalty inclination, the data are collected from the top three Taiwanese airlines, but may not adequately reveal the generalizability of the results. This is a limitation of this study, and thus a market survey that includes non-Taiwan based airlines may provide future research suggestions. In terms of the limitation of the research method, although the empirical result stands from a non-probability convenience sample from the top three Taiwanese airlines, the generalization of the findings to all passengers or non-sampling passengers might be limited.

Due to the latest developments of Taiwan's political situation following the presidential election, cross-trait tourists coming from Mainland China has showed a cooling trend. Moreover, the market shares of low-cost carriers have increased due to more flights are taking off and landing at local airports like Taichung airport and Kaohsiung airport. The product substitutions of low-cost carriers should pay more attention for the recommendation in the future study. However, due to similar customer characteristics and needs, other international airlines or low-cost carriers could use this study's empirical results as a reference to reconsider how to deliver customer loyalty planning.

\section{References}

Alexandris, K., Dimitriadis, N., \& Markata, D. (2002). Can perceptions of service quality predict behavioral intentions? An exploratory study in the hotel sector in Greece. Managing Service Quality, 12(4), 224-231. http://dx.doi.org/10.1108/09604520210434839

Anderson, E. W., \& Sullivan, M. W. (1993). The antecedents and consequences of customer satisfaction. Marketing Science, 12(Spring), 125-143.

Anderson, J. C., \& Gerbing, D. W. (1988). Structural equation modeling in practice: A review and recommended two-step approach. Psychological Bulletin, 103(3), 411-423.

Bagozzi, R. P., Yi, Y., \& Phillips, L. W. (1991). Assessing construct validity in organizational research. Administrative Science Quarterly, 36(3), 421-458.

Bitner, M. J., \& Hubbert, A. R. (1994). Encounter satisfaction vs. overall satisfaction vs. quality, In Rust, R.T. \& Oliver, R.L. (Eds.). Service quality: new directions in theory and practice, Sage, Thousand Oaks, CA. pp. 72-94. 
Chen, C. F., \& Chen, F. S. (2010). Experience quality, perceived value, satisfaction and behavioral intentions for heritage tourists. Tourism Management, 31(1), 29-35. https://doi.org/10.1016/j.tourman. 2009.02.008

Chou, C. M., Hsieh, S. F., \& Tseng, H. P. (2014). The crowding-out effects of Chinese tourists on inbound tourism in Taiwan. Tourism Economics, 20(6), 1235-1251. https://doi.org/10.5367/te.2013.0342

Civil Aeronautics Administration, MOTC (Ministry of Transportation and Communications, Taiwan, R. O. C.)

Clemes, M. D., Gan, C. E. C., Kao, T. H., \& Choong, M. (2008). An empirical analysis of customer satisfaction in international air travel. Innovative Marketing, 4(1), 49-62.

Committee for Aviation Industry Development, Ministry of Economic Affairs, Taiwan, R. O. C. Available from Internet: http://www.casid.org.tw/casid [cited 18 April 2016].

Connor, D., \& Davidson, J. (1997). Marketing your consulting and professional services. John Wiley and Sons, New York.

Cronin, J. J., \& Taylor, S. A. (1992). Measuring service quality: A reexamination and extension. Journal of Marketing, 56(3), 55-68.

Cronin, J. J., Brady, M., \& Hult, G. (2000). Assessing the effects of quality, value and customer satisfaction on consumer behavioral intentions in service environments. Journal of Retailing, 76(2), 193-218. http://dx.doi.org/10.1016/S0022-4359(00)00028-2

Culiberg, B. (2010). Identifying service quality dimensions as antecedents to customer satisfaction in retail banking. Economic and Business Review, 12(3), 151-166.

Dodds, W. B., \& Monroe, K. B. (1985). The effect of brand and price information on subjective product evaluation. Advances on Consumer Research, 12(1), 85-90.

Elgin, A., \& Nedunchezhian, V. R. (2012). An analytical study into the effects of service quality on the perception of domestic airline image with special reference to frequent fliers at Trivandrum city in India. European Journal of Social Sciences, 29(4), 521-527.

EVA Airway Corp., Available from Internet: http://www.evaair.com [cited 25 May 2016].

Far Eastern Air Transport Corp. (FAT), Available from Internet: http://www.fat.com.tw [cited 31 May 2016].

Fredericks, J. O., \& Slater, J. M. (1998). What does your customer really want? Quality Progress, 31(1), 63-65. http://dx.doi.org/10.3846/16111699.2013.858076

Hau, K. T., \& Marsh, H. W. (2004). The use of item parcels in structural equation modelling: non - normal data and small sample sizes. British Journal of Mathematical and Statistical Psychology, 57(2), 327-351.

Hellier, P. K., Ceursen, G. M., Carr, R. A., \& Rickard, A. (2003). Customer repurchase intention: A general structural equation model. European Journal of Marketing, 37(11/12), 1762-1800.

Hitt, M. A., Bierman, L., Shimizu, K., \& Kochhar, R. (2001). Direct and moderating effects of human capital on the strategy and performance in professional service firms: A resource based perspective. Academy of Management Journal, 44(1), 13-28.

Homsombat, W., Lei, Z., \& Fu, X. (2014). Competitive effects of the airlines-within-airlines strategy-pricing and route entry patterns. Transportation Research Part E: Logistics and Transportation Review, 63(March), 1-16.

Hussain, R., Nasser, A. A., \& Hussain, Y. K. (2015). Service quality and customer satisfaction of a UAE-based airline: An empirical investigation. Journal of Air Transport Management, 42(January), 167-175. http://dx.doi.org/10.1016/j.jairtraman.2014.10.001

IATA (The International Air Transport Association), Strong demand for air travel rises in 2014' Press Release No. 5, Geneva, February 5, 2015. Available from Internet: http://www.iata.org/pressroom/pr/Pages/2015-02-05-01.aspx

Jaworski, B. J., \& Kohli, A. K. (1993). Market orientation antecedents and consequences. Journal of Marketing, 57(3), 53-70.

Juran, J. M. (1991). World War II and the quality movement. Quality Progress, 24(12), 19-24.

Keller, K. L. (1993). Conceptualizing, measuring, and managing customer-based brand equity. Journal of Marketing, 57(1), 1-22.

Kor, Y. Y. (2003). Experience-based top management team competence and sustained growth. Organization 
Science, 14(6), 707-719.

Kristensen, K., Martensen, A., \& Gronholdt, L. (1999). Measuring the impact of buying behavior on customer satisfaction. Total Quality Management, 10(4/5), 602-614. http://dx.doi.org/10.1080/0954412997587

Kuo, Y. F., Hu, T. L., \& Yang, S. C. (2013). Effects of inertia and satisfaction in female online shoppers on repeat-purchase intention: The moderating roles of word-of-mouth and alternative attraction. Journal of Service Theory and Practice, 23(3), 168-187. https://doi.org/10.1108/09604521311312219

Kuo, Y. F., Wu, C. M., \& Deng, W. J. (2009). The relationships among service quality, perceived value, customer satisfaction, and post-purchase intention in mobile value-added services. Computers in Human Behavior, 25(4), 887-896. https://doi.org/10.1016/j.chb.2009.03.003

Lai, W. T., \& Chen, C. F. (2011). Behavioral intentions of public transit passengers-The roles of service quality, perceived value, satisfaction and involvement. Transport Policy, 18(2), 318-325.

Lee, M. C. (2006). Applying TQM, CMM and ISO 9001 in knowledge management for software development process improvement. International Journal of Services and Standards, 2(1), 101-115.

Mainland Affairs Councils, Taiwan, R. O. C. Available from Internet: http://www.mac.gov.tw

Parasuraman, A., \& Grewal, D. (2000). The impact of technology on the quality-value-loyalty chain: A research agenda. Journal of the Academy of Marketing Science, 28(4), 168-174.

Parasuraman, A., Zeithaml, V. A., \& Berry, L. L. (1985). A conceptual model of service quality and its implication. Journal of Marketing, 49(Fall), 41-50.

Parasuraman, A., Zeithaml, V. A., \& Berry, L. L. (1988). SERVQUAL: A multiple item scale for measuring customer perceptions of service quality. Journal of Retailing, 64(1), 12-40.

Parasuraman, A., Zeithaml, V. A., \& Berry, L. L. (1994). Alternative scales for measuring service quality: A comparative assessment based on psychometric and diagnostic criteria. Journal of Retailing, 70(3), 201-230.

Park, C. W., Jaworski, B. J., \& Maclnnis, D. J. (1986). Strategic brand concept-image management. Journal of Marketing, 50(4), 135-145.

Park, J. W., Robertson, R., \& Wu, C. (2004). Modeling the impact of airline service quality and marketing variables on passengers' future behavioural intentions. Transportation Planning and Technology, 29(5), 359-381.

Peach Aviation Corp., Available from Internet: http://www.flypeach.com [cited 2 June 2016].

Raquel, Sánchez-Fernández, \& Ángeles, M. Iniesta-Bonillo. (2007). The concept of perceived value: A systematic review of the research. Marketing Theory, 7(4), 427-451. http://mtq.sagepub.com/cgi/content/abstract/7/4/427

Roberts, P. W., \& Dowling, G. R. (2002). Corporate reputation and sustained superior financial performance. Strategic Management Journal, 23(12), 1077-93. http://dx.doi.org/10.1002/smj.274

Romaniuk, J., \& Sharp, B. (2003). Measuring brand perceptions: Testing quantity and quality. Journal of Targeting, Measurement and Analysis, 11(3), 218-229. https://doi.org/10.1057/palgrave.jt.5740079

Scoot Pte. Ltd., Available from Internet: http://www.flyscoot.com [cited 7 July 2016].

Seth, N., Deshmukh, S. G., \& Vrat, P. (2005). Service quality models: a review. International Journal of Quality \& Reliability Management, 22(9), 913-949. https://doi.org/10.1108/02656710510625211

Sirdeshmukh, D., Jagdip, S., \& Barry, S. (2002). Consumer trust, value, and loyalty in relational exchanges. Journal of Marketing, 66(1), 15-37. http://dx.doi.org/10.1509/jmkg.66.1.15.18449

Sweeney, J. C., \& Soutar, G. N. (2001). Consumer perceived value: The development of a multiple item scale. Journal of Retailing, 77(2), 203-220. https://doi.org/10.1016/S0022-4359(01)00041-0

Tasci, A. D. A. (2016). Consumer value and brand value: Rivals or allies in consumer-based brand equity? Tourism Analysis, 16(4), 481-496.

Tigerair Corp., Available from Internet: http://www.tigerair.com/tw/zh [cited 31 August 2016].

Tourism Bureau in Taiwan, MOTC. Available from Internet: Ministry of Transportation and Communications, Taiwan, R. O. C., annual statistics data reports. http://www.taiwan.net.tw [cited 26 April 2016]. 
TransAsia Corp., Available from Internet: http://www.tna.com.tw/index.aspx [cited 25 July 2016].

Tsaur, S. H., Chang, T., \& Yen, C. H. (2002). The evaluation of airline service quality by Fuzzy MCDM. Tourism Management, 23(2), 107-115. https://doi.org/10.3727/108354216X14653218477561

V Air Corp., Available from Internet: http://www.flyvair.com/zh [cited 31 October 2016].

Wang, S., Qu, X., \& Yang, Y. (2015). Estimation of the perceived value of transit time for containerized cargoes. Transportation Research Part A: Policy and Practice, 78(C), 298-308.

Wang, Y. H., \& Tsai, C. F. (2014). The relationship between brand image and purchase intention from award winning mutual funds. The International Journal of Business and Finance Research, 8(2), 27-40.

Wang, Y., Lo, H., \& Yang, Y. (2004). An integrated framework for service quality, customer value, satisfaction, evidence from china's telecommunications industry. Information Systems Frontiers, 6(4), 330-337.

$\mathrm{Wu}, \mathrm{L}$. (2011). Satisfaction, inertia, and customer loyalty in the varying levels of the zone of tolerance and alternative attractiveness. Journal of Services Marketing, 25(5), 310-322. http://dx.doi.org/10.1108/08876041111149676

Zeithaml, V. A. (1988). Consumer perceptions of price, quality and value: a means-end model and synthesis of evidence. Journal of Marketing, 52(July), 2-22.

Zeithaml, V. A., Berry, L. L., \& Parasuraman, A. (1996). The behavioral consequences of service quality. Journal of Marketing, 60(April), 31-46.

Appendix 1 (The questionnaire: question items 1-33)

\section{A.1 Service Quality}

\section{A.1.1 Tangible attributes}

1 Aircraft appearance is attractive to tourists

2 Cabin \& seating space feel comfortable

3 Onboard audio \& video equipment and multimedia content are new and appealing

\section{A.1.2 Reliability}

4 Flight is consistently on time

5 Provision of a secure and safe service

6 The overall flight quality is trustworthy

\section{A.1.3 Responsiveness}

7 Customer complaints are properly processed

8 Service personnel can immediately respond to customers' needs

9 Patiently listen to customer complaints and assist them to resolve issues

\section{A.1.4 Assurance}

10 Exhibit professional service capability

11 Staff have good communication skills

12 Provide healthy and delicious food \& drink

\section{A.1.5 Empathy}

13 Service personnel take the initiative to assist the customer

14 Strive to satisfy the tourists' individual needs

15 Commendable overall service attitude

\section{A.2 Brand Image}

\section{A.2.1 Functional benefits}

16 The airline offers sufficient choices for the number of flights

17 The hardware features of this airline are excellent 


\section{A.2.2 Symbolic benefits}

18 Positive brand image enticed me to book this airline

19 Selection of this airline was due to celebrity endorsements

\section{A.2.3 Experiential benefits}

20 Additional services (such as generous baggage allowance and other offerings) raise customer satisfaction

21 Overall onboard facilities experience

\section{A.3 Perceived Value}

\section{A.3.1 Perceived quality}

22 Efficient reporting system, boarding, and baggage claim

23 Flight arrangements match my ideal travel time

\section{A.3.2 Emotional value}

24 Flight attendants' attitude are cordial and affable

25 Duty-free goods sold on board

\section{A.3.3 Social value}

26 The airline has a positive reputation

\section{A.3.4 Price}

27 Pricing is more expensive, but it provides a premium service

\section{A.4 Customer Loyalty}

\section{A.4.1 Recent purchase activities}

28 Influenced by discount promotional activities to select this airline to buy

29 Positively influenced when the airline introduces new aircraft facilities to buy

\section{A.4.2 Repurchase intention}

30 When traveling again I would still choose this airline

31 Even if other airlines offer lower prices, I will still choose this airline

\section{A.4.3 Recommendation intention}

32 I would recommend this airline to my families and friends

33 I am glad to share this positive airline experience with others

\section{Copyrights}

Copyright for this article is retained by the author(s), with first publication rights granted to the journal.

This is an open-access article distributed under the terms and conditions of the Creative Commons Attribution license (http://creativecommons.org/licenses/by/4.0/). 